Respiration 2018;95:212-214

DOI: $10.1159 / 000484568$

\section{Treatment Step 1 for Asthma Should Not Be Left Blank, and SABA-Only Might Not Be a Treatment Step 1 Option for Asthma}

\section{Luis Javier Nannini Nadia S. Neumayer}

Pulmonary Section, Hospital "E. Perón”, Granadero Baigorria, Argentina; Universidad Nacional Rosario, Rosario, Argentina

We have found a great difference, at least in the treatment diagrams, between the GINA (ginasthma.com) [1] and the British Thoracic Society guidelines [2] (BTS/SIGN) for the management of asthma. The recently updated BTS/SIGN guidelines [2] show an outstanding change in step 1 . They immediately recommend a low dose of inhaled corticosteroids (ICS); while the GINA guidelines leave the first option for step 1 blank (Fig. 1) [1]. In this way, the BTS/SIGN guidelines have eradicated short-acting $\beta_{2}$ agonists (SABA) as the unique option (Fig. 2). However, the explanatory text of both treatment diagrams stresses the risks of frequent SABA-only use and recommends that, with some exceptions, ICS should be prescribed to most adults with asthma. Hence, in the BTS/SIGN guidelines, SABA-only treatment is still recommended for patients who have "infrequent short-lived wheeze" [2, figure 2, p. 78], and the more detailed information on page 66 states that ICS should be considered for any patients with "an asthma attack in the last 2 years, using SABA 3 times a week or more, symptomatic 3 times a week or more, waking one night a week." By contrast, in the GINA guidelines 2017 [1, p. 42], SABA-only treatment is reserved for patients with "asthma symptoms less than twice a

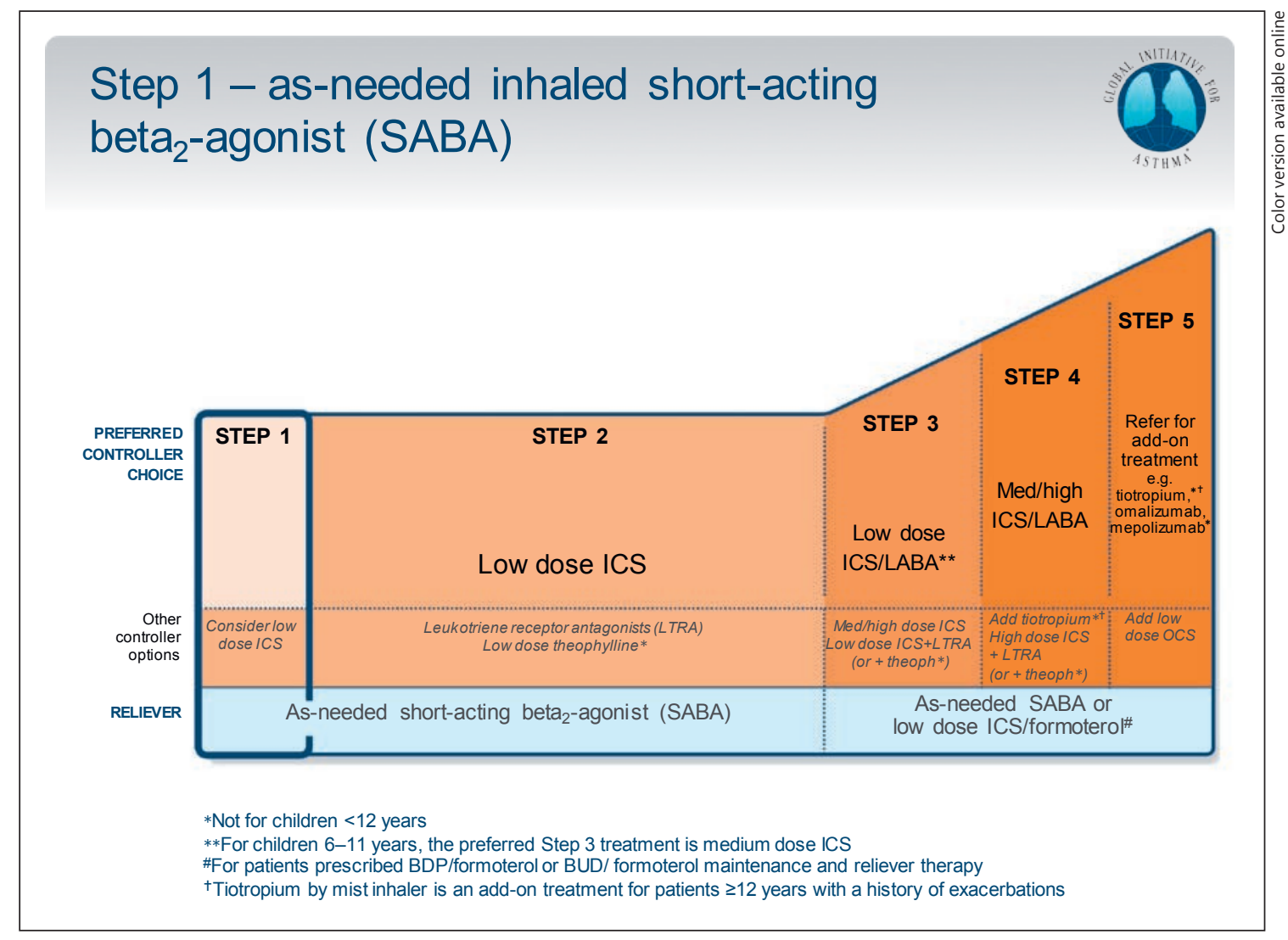

Fig. 1. GINA teaching slide set. This figure is reproduced from Global Strategy for Asthma Management and Prevention, Global Initiative for Asthma (GINA) 2017 by kind permission of the Global Initiative for Asthma [1].

\section{KARGER}

(C) 2017 S. Karger AG, Basel

E-Mail karger@karger.com www.karger.com/res
Luis Javier Nannini

Pulmonary Section, Hospital "E. Perón”

Universidad Nacional Rosario

San Martín 1645, Granadero Baigorria S2152EDD (Argentina)

E-Mail ljnannini@hotmail.com 
month, no waking due to asthma in last month, and no risk factors for exacerbations, including no exacerbations in the last year;" with ICS treatment recommended for patients with any risk factors for exacerbations, asthma symptoms/SABA use twice a month or more, or waking due to asthma once a month or more (BOX 3-4; p. 42). Thus the BTS/SIGN guidelines recommend SABA-only treatment for more patients than the GINA guidelines do, which is the opposite of the conclusion drawn from the diagrams. It seems that some clarification of the treatment diagrams in both documents $[1,2]$ is warranted.

Nevertheless, we believe the firm recommendation of ICS at step 1 was an innovative, bold, and evidence-based decision. Why?

1. Studies have shown ongoing airway inflammation and airway remodeling in adolescents in clinical remission of atopic asthma $[3,4]$.

2. Elevated exhaled nitric oxide levels and bronchial biopsy evidence of airway inflammation have been found in patients with mild intermittent asthma [5].

3. Bronchoconstriction generates excessive mechanical forces within the airways that distort tissue cells [6]. This phenomenon might occur every time asthmatic subjects inhale SABA as needed.
4. Early initiation of low-dose ICS leads to a greater improvement in lung function [7, 8]. After 24 months of asthma symptoms, budesonide at a dosage of $800 \mu \mathrm{g} /$ day is needed to obtain a similar improvement to $200 \mu \mathrm{g} /$ day budesonide in patients with $<12$ months of asthma symptoms [9].

What else is needed to establish ICS as the first option at step 1? Long-acting bronchodilator agonists (LABA) alone are expressly contraindicative even as reliever agents [1]. The same argument should be applied to SABA. There is an association between SABA overuse and the risk of death due to asthma $[9,10]$.

\section{Author Contributions}

The concept of the manuscript and interpretation of the data were done by L.J.N. with an important intellectual share by N.S.N.

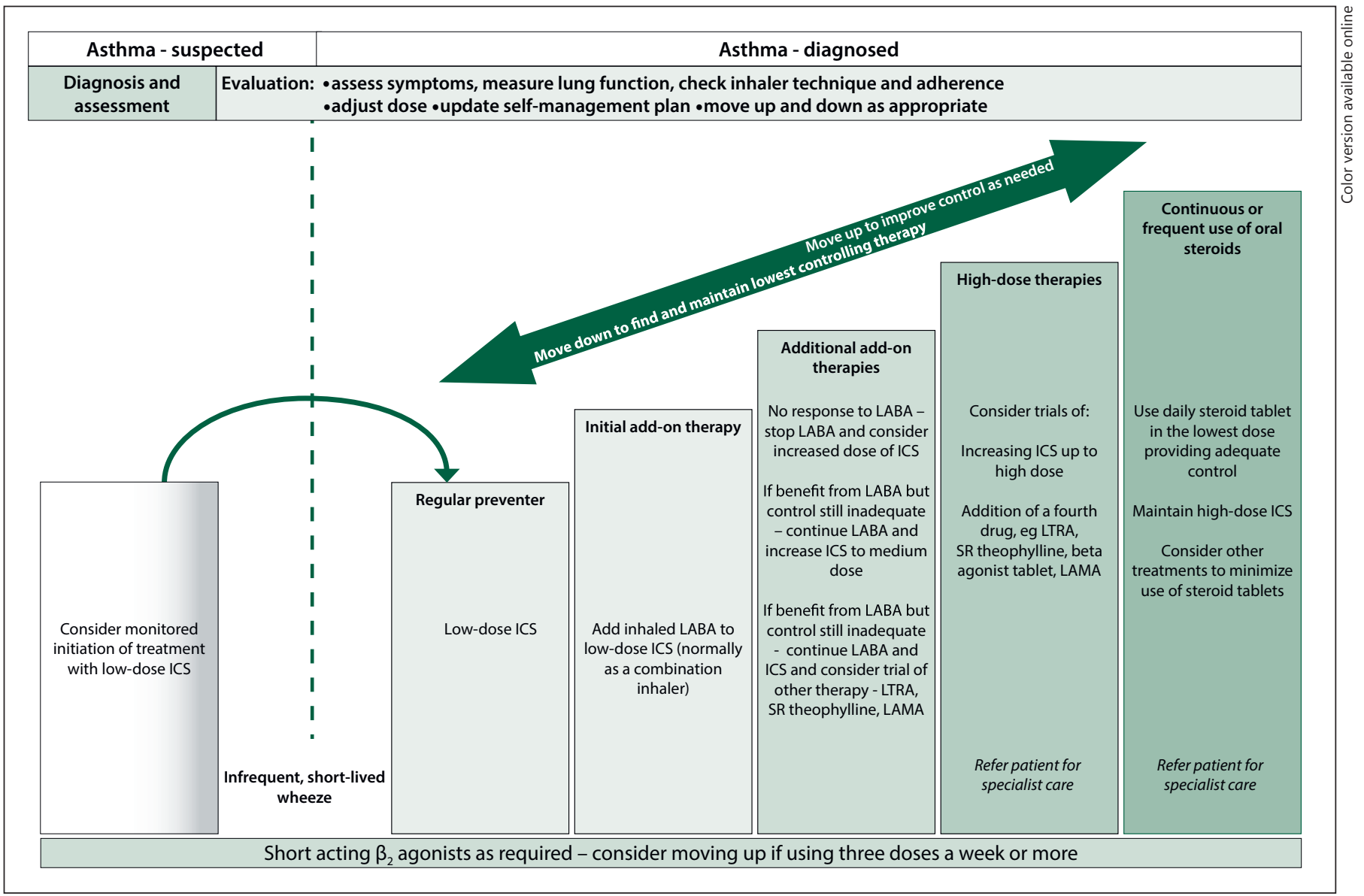

Fig. 2. Summary of managements in adults. This figure is reproduced from BTS/SIGN British Guideline on the Management of Asthma: A National Clinical Guideline 2016 by kind permission of the British Thoracic Society [2]. 


\section{References}

1 GINA Executive Committee: Global Strategy for Asthma Management and Prevention, Global Initiative for Asthma (GINA) 2017. www.ginasthma.org (last accessed: March 16, 2017).

2 British Thoracic Society (BTS)/Scottish Intercollegiate Guidelines Network (SIGN): British Guideline on the Management of Asthma: A National Clinical Guideline 2016. Edinburgh, SIGN, 2016. (QRG 153). www.brit-thoracic.org.uk (last accessed: April 10, 2017).

3 Spallarossa D, Battistini E, Silvestri M, Sabatini F, Fregonese L, Brazzola G, Rossi GA: Steroid-naive adolescents with mild intermittent allergic asthma have airway hyperresponsiveness and elevated exhaled nitric oxide levels. J Asthma 2003;40:301-310.

4 Vignola AM, Chanez P, Campbell AM, Souques F, Lebel B, Enander I, Bousquet J: Airway inflammation in mild intermittent and in persistent asthma. Am J Respir Crit Care Med 1998;157:403-409.

5 van den Toorn LM, Overbeek SE, de Jongste JC, Leman K, Hoogsteden HC, Prins JB: Airway inflammation is present during clinical remission of atopic asthma. Am J Respir Crit Care Med 2001;164:2107-2113.
6 Grainge CL, Lau LCK, Ward JA, Dulay V, Lahiff G, Wilson S, Holgate S, Davies DE, Howarth PH: Effect of bronchoconstriction on airway remodelling in Asthma. N Engl J Med 2011;364:2006-2015.

7 Suissa S, Ernst P, Boivin JF, et al: A cohort analysis of excess mortality in asthma and the use of inhaled beta-agonists. Am J Respir Crit Care Med 1994;149:604-610.

8 Busse WW, Pedersen S, Pauwels RA, et al: The Inhaled Steroid Treatment As Regular Therapy in Early Asthma (START) study 5-year followup: effectiveness of early intervention with budesonide in mild persistent asthma. J Allergy Clin Immunol 2008;121:1167-1174.

9 Selroos O: Effect of disease duration on dose - response of inhaled budesonide in asthma. Respir Med 2008;102:1065-1072.

10 Spitzer WO, Suissa S, Ernst P, et al: The use of beta-agonists and the risk of death and near death from asthma. N Engl J Med 1992;326:501-506. 